\title{
Occupied Istanbul as a Cominternian Hub: Sailors, Soldiers, and Post-Imperial Networks (1918-1923)
}

\author{
BURAK SAYIM* \\ E-mail: burak.sayim@graduateinstitute.ch
}

\begin{abstract}
Between 1918 and 1923, Istanbul was the capital of a defeated empire and occupied by the "interallied" forces composed of Britain, France, and Italy. Notwithstanding, or precisely due to, these conditions, it functioned as a vibrant hub of global communist militancy. This article explores the brief history of occupied Istanbul and discusses different agents and aspects of communist network-making. It underlines the agency of two neglected actors: a multinational body of communist sailors who connected Istanbul and its communists to European, Middle Eastern, and Soviet ports; and European and colonial soldiers stationed in Istanbul, who counterintuitively contributed to these connections. Finally, it shows how Istanbul, as the multiethnic and multilinguistic soon-to-be-former capital of the Ottoman Empire, provided a fertile ground for communist connections.
\end{abstract}

Keywords: Istanbul, Communist International, post-Ottoman, transnational, sailors

Recently, historians have started paying attention to the interconnected worlds of the global left-wing movements. In these studies, the Communist International (Comintern, or the Third International), as a self-proclaimed world party, is bound to be a key actor, even a protagonist. However, the theoretical possibilities that such study offers remains under-explored. Michael Goebel points out this curiosity when he states that "ironically, as historians have become more interested in globalisation in recent decades, their curiosity in communism and in the Comintern, an internationalist organisation if ever there was one, has receded."1 Addressing this issue and drawing upon the emerging interest in the Communist International during the last years, this text offers a case study of the transnational and interconnected world of the Communist International.

The history of the Comintern did indeed receive its fair share of attention, starting even before its demise and with highly different interpretations. C. L. R. James's work 
was a contemporary onslaught from the left against the Stalinist degeneration of the Communist International. ${ }^{2}$ William Z. Foster wrote the same history from the standpoint of the Soviet orthodoxy. ${ }^{3}$ E. H. Carr provided a detailed analysis of the significant sections of the International on the eve of its liquidation. ${ }^{4}$ Duncan Hallas's work is an introduction for young militants, rather than a thorough historical study. ${ }^{5}$ Pierre Broué's monumental work remains the most comprehensive account of the Comintern history, with a keen eye for its neglected sections. ${ }^{6}$ Serge Wolikow gives an exact picture of the organisational structure of the Communist International. ${ }^{7}$ Silvio Pons's book also delves into questions regarding the Communist International, albeit in a limited and Eurocentric manner. ${ }^{8}$ Other works follow the evolution of the Comintern line on particular issues, such as fascism or the united front. ${ }^{9}$

Although many of these works remain valuable sources, they limit themselves to the political decisions at the top of the Communist International. However, in looking more deeply at this transnational world, possibilities emerge that historians recently started to explore. One might take a regional standpoint and explore the Cominternians crisscrossing this space, as Margaret Stevens does for the Caribbean world. ${ }^{10}$ Or track the paper trail left by one of the sundry larger-than-life militants of this organisation, traversing borders and oceans to spread the word. ${ }^{11}$ Or, as Brigitte Studer does masterfully, one might also tackle the transnational way of life at the very centre of this international organisation. ${ }^{12}$

This study undertakes another way of looking into the transnational world of the Communist International, namely by localising it within the limits of a city, although the choice of Istanbul might seem counterintuitive. In the 1920s, while the fledgeling Communist International was making headway worldwide, gathering tens of thousands of people under its banner from Paris to Jakarta, Buenos Aires to Shanghai, its political clout was felt less intensely in Istanbul. No massive communist party was there to become the point of attraction in the city. As various nationalist organisations grew more robust in the Istanbuli scene, the British-backed Socialist Party firmly held the reins of the workingclass movement. ${ }^{13}$ Due to these circumstances, histories of Istanbul's Greek, Turkish, or Russian communist groupings are either mentioned anecdotally or utterly absent in the accounts of what would become their respective national communist parties, let alone the histories of the Communist International. In other words, Istanbul in the early 1920s was not on the map of global communism, as far as historians were concerned. ${ }^{14}$

Yet the study of Istanbul provides a useful starting point to address some blind spots in the history of interwar communism. The city functioned as a vital node in global communist networks. The interconnectedness of communist spaces is no novelty. However, this study underlines some underappreciated features of it.

First, it highlights the role of the multinational body of communist sailors in establishing unexpected connections between communist militants of faraway lands. Long before global communism made its appearance on the world political scene, Istanbul straddled the maritime routes connecting European, Middle Eastern, and Russian ports. Before the Great War, Istanbul stood out as a significant hub of cultures and ideas, and the various types of radicalism were no exception. ${ }^{15}$ By the early 1920 s, this position meant extensive connections with the strong communist-led working-class movement of Europe, the 
national liberation struggles in the Middle East, and the new Soviet power. Accordingly, Istanbul played a prominent part in the global communist movement, not due to any massive communist movement of its own, but as an international node between Russia, Europe, and the Middle East. As they did across the globe, anonymous communist sailors forged connections between these worlds. This study will attempt to do justice to their historical agency.

The Comintern mobilised an international body of sailors-whom they considered "almost naturally internationalist" _ _ as the "trait d'union" of the communist movement. Through the 1920 s, the Comintern set up centres in numerous important seaports to organise sailors frequenting these ports. Vladivostok, Hamburg, and Marseille were notable. The Comintern archives show a Thessaloniki centre project, dated 1924, which operated through "comrade sailors" and spread Arabic- and Turkish-language communist literature to cities such as Beirut, Alexandria, and Haifa, as well as Istanbul, through maritime connections. ${ }^{17}$

A second collective actor that I address are the body of communist or sympathising soldiers. The occupation of Istanbul from November 1918 to October 1923 brought hundreds of French, British, Italian, and Greek soldiers to Istanbul, along with North African French and South Asian British soldiers. Although their role was to subdue the capital of a defeated nation for the benefit of imperialist powers, the young soldiers often came from poor peasant and working-class backgrounds. During this period, European war veterans stood as an essential part of the revolutionary wave rocking the continent. Arditi del Popolo in Italy, ARAC (Association républicaine des anciens combattants) in France, and Asia Minor veterans in Greece constituted a pivotal component of revolutionary politics. ${ }^{18}$ In this context, the presence of soldiers from four European armies in Istanbul is remarkable. Just like their peers in their respective homelands, the aftershocks of the Soviet Revolution and the revolutionary movements across the globe would have an effect on them. This phenomenon showed itself in Istanbul. The foreign soldiers brought their aspirations and existing networks with them. Sometimes they undertook communist propaganda themselves within their regiments, but more often they were on the receiving end of defeatist propaganda by different communist groups in Istanbul.

Third, all this Cominternian networking occurred against the backdrop of early postimperial Istanbul. Its position at the centre of post-Ottoman space ${ }^{19}$ made it a fertile ground for communist network-making, and the Comintern acted upon this. The city harboured sizeable Turkish, Greek, and Armenian populations and an ever-increasing Russian emigré community. Its past as an imperial capital meant that significant Arabic, Bulgarian, Albanian, and Georgian communities also populated Istanbul. Add the occupying armies and the European population that accompanied them, and it is easy to see that Istanbul was nothing short of a true metropolis and a hospitable ground for the Comintern. The linguistic richness in Istanbul facilitated its inclusion in the networks of the global communist movement.

These elements illustrate what is so unique and worthy of interest in occupied Istanbul. Not only are there multiple communist actors present, but there is a remarkable variety of communist actors. Their interaction, both with one another and with Istanbul, is strikingly 
different. European soldiers of the Allied powers brought the phenomenon of left-wing soldier/veteran militancy in postwar Europe to Istanbul. In their case, Istanbul was merely a battleground where they happened to be. There, they continued to wage the intra-French, Italian, or Greek fights of their homeland. As an international maritime node, Istanbul gathered sailors from all over the Mediterranean and the Black Sea. For them, Istanbul was just one part, albeit sometimes a privileged one, of a radical transnational space consisting of different ports and seas. For the left-wing Bulgarian, Jewish, or Armenian militants, Istanbul was still the centre of what was once a multiethnic and multireligious imperial space where transnational networks and alliances could be forged. Turkish militants, on the other hand, had a troubled relationship with the old imperial capital. Ankara was emerging as the epicentre of the Turkish National Revolution, and the exodus of a sizeable body of communist militants towards Ankara was underway. Istanbul became Shanghai to their Guangzhou, Saigon to their Hanoi. Some felt the need to be there as their responsibility to the emerging working class in the city, but they also worked as the partisans of the new revolutionary capital within the captive imperial centre. This simultaneous existence of the variety of communist actors with different reasons to be there and with different relationships with the city's political scene makes occupied Istanbul an apt location to see the post-World War I Cominternian habitus in microcosm.

Zooming in to such cases fills a gap in the study of interwar communism. In its genesis, the Comintern did not conceive of itself as an alliance of disparate national parties. Instead, these parties were to form the national battalions of one world party. Not incidentally, in the 1920s, French, Syrian, and Egyptian communist parties signed their official papers as the French, Syrian, or Egyptian Section of the Communist International. ${ }^{20}$ This practice would soon fall out of fashion, and its spirit stood in direct contrast with the later period of the Communist International and especially that of the Cold War/Cominform period. Often, interwar communism has been conceived as the mere sum of different communist parties. Cases such as occupied Istanbul, where the variety of communist actors makes the interconnectedness of the world communist movement easier to discern, are useful as an alternative historical glance, providing a glimpse of the transnational and interwoven nature of the early Cominternian world.

\section{Setting the Transnational Communist Scene in Istanbul}

As the capital of a defeated empire, Istanbul came under the de facto control of British forces immediately after the end of World War I in November 1918. This turned into an outright occupation on 16 March 1920, with the raid on Şehzadebaşı barracks by British troops, leaving a number of Ottoman casualties, that would only end in 1923, after the decisive victory of the Turkish National Liberation War in Anatolia. In the wake of the Great War, in addition to Istanbul, the Allied forces occupied various parts of the Anatolian heartlands of the Ottoman Empire. Greek troops occupied the Aegean region around Izmir and started moving farther inland in Anatolia. Italian forces seized Antalya and its sector as the French tried to force their way into the Cilicia region. 
With Britain joined with its wartime allies France and Italy, Istanbul came under the control of an uneasy coalition of interallied forces. The British immediately abolished the Ottoman parliament and sent the pro-resistance elements within the parliament to exile in Malta. This move was conceived as the final blow to Ottoman resistance. The national liberation movement emerging in Anatolia made good use of this political shortsightedness and quickly gathered a new National Assembly in the backwater town of Ankara, creating a situation of dual power. Until the final victory of the forces gathered around the new National Assembly against both the Greek occupation and the remnant of the old imperial authority in 1923, Istanbul, the old imperial capital, lived in a political limbo under tripartite occupation. ${ }^{21}$

In these years, the image of foreign warships threatening the Ottoman capital marked the spirits of contemporary observers, communist and non-communist alike. The famous quip attributed to Mustafa Kemal that "just as they have come, so too they will go" would soon be a part of the official historiography of Turkey. ${ }^{22}$ Nazım Hikmet, then a young cadet and a future communist leader and world-renowned poet, later recalled his feelings before this scene: "The sea of Istanbul is jam-packed with dreadnoughts, cruisers, torpedoes, and carriers painted in various colours. How many times have I watched this enemy, this contemptuous, this lead steel crowd, crawling with anger." ${ }^{\text {"3 }}$ Similarly, Vanlı Kazım, who would become a prominent communist militant in occupied Istanbul, felt anger at this sight: "My joy was endless while passing through the Marmara. This joy, however, did not last long. The Bosphorus was filled with enemy ships. The streets and avenues were full of American, British, French and Italian soldiers. This scene was shattering and crushing my heart, and, as I looked around, it was increasing my will to fight." ${ }^{24}$ Magdeleine Marx, as well as the Executive Committee of the Communist International (ECCI), would make similar remarks. ${ }^{25}$

To zoom in on Istanbul's communist scene, let us start with one neighbourhood of Istanbul, Karaköy, to set the stage through its political landscape and untangle things from there. The location of the Karaköy district is quite strategic. Right next to it stands the vibrant port of Galata, where sailors coming from other Mediterranean or Black Sea ports carry their luggage full of stories, trinkets, and - who knows - maybe even a subversive paper. On the other side of Karaköy, you have the highly Europeanised district of Pera. There, one might take an Esperanto class, ${ }^{26}$ catch the latest movie by D. W. Griffith, ${ }^{27}$ bump into an arrogant British officer, dance to the most recent hit of a Russian jazz band, ${ }^{28}$ and even, if lucky, watch French mutineers march to the tune of "La Jeune Garde," a classical socialist air. ${ }^{29}$

Back in Karaköy, we find a brewery called La Sirène (The Mermaid), located on Mumhane Street, which is also home to the Social Democratic Party. The name of the brewery is apt, given that a sizeable part of the clientele are sailors. Both French and Ottoman noncommissioned officers often mingle with this clientele. The Mermaid is particularly interesting as it is a place not just for cheap beer and social interaction but also for distributing clandestine communist publications. Several Laz sailors are among the regulars in this place. ${ }^{30}$ They sell a communist paper in the Ottoman Turkish language called Ziya (The Light) published by the Communist Party of Bulgaria (CPB) in Sofia 
and smuggled to Istanbul by like-minded sailors. At least one of the four owners of the Mermaid was in touch with Vnechtorg, the Soviet foreign trade entity that provided him with Bolshevik publications and flyers. ${ }^{31}$

The sailors' chapter of the Union Internationale des Travailleurs (International Union of Workers, hereafter UIT) was located a little farther on in the same street. This particular local of the UIT was home to a rather extensive Marxist library, filled with Greek and French works, brought mostly from Egypt and France. Its two hundred-odd members, mostly Greek but also Russian, Armenian, and Turkish sailors, gather for weekly conferences, which always end with singing the "Internationale" under an embroidered red flag - courtesy of the "Sebastopol Port Bureau of International Propaganda amongst Transport Workers.",32

Now, let us leave Mumhane Street and continue towards the Arap Camii, or the Arab Mosque, barely a ten-minute walk from the UIT local. There we find a coffeehouse called Kürkçübaşı operated by one of the communist Laz sailors of La Sirène. He went by "Mehmet Bey," a nom de guerre, and was always seen sporting a pistol and in the company of two likewise armed comrades. According to the French reports, this coffeehouse functioned as a meeting ground for Bulgarian and Turkish communists. ${ }^{33}$

In Sirkeci, right next to the district of Karaköy, was yet another communist club, this time with a militant base composed mostly of Jewish communists. The colonial soldiers of the British and French armies, most notably Muslim South Asians and Algerians, were reportedly among the regulars at its meetings. ${ }^{34}$ Not incidentally, South Asian soldiers of the British Army were stationed in Beyazıt, near Sirkeci, until British authorities had qualms about increasing interactions between their colonial soldiers and the local population, including during Ramadan prayers. ${ }^{35}$

\section{Soldiers, Anti-Colonialism, and Anti-Militarism}

French soldiers' increasing interactions with the communist clientele at La Sirène, as mentioned earlier, was part of a concern for French occupation authorities in Istanbul and beyond. Ongoing defeatist propaganda by the French Communist Party (PCF) was a thorn in the side of the French army. In 1919, a mutiny led by André Marty rocked the French navy, with some mutineers also demonstrating in Istanbul and singing the "Internationale." ${ }^{36}$ The head of the Southern Bureau of the Communist International, in charge of Istanbul and the Balkans, was none other than Jacques Sadoul, ${ }^{37}$ a French officer turned communist, a renegade of sorts as far as the French top brass was concerned. In 1922 he famously took a Soviet submarine to participate in a communist congress in Ankara. ${ }^{38}$ In 1921, the French Minister of War, Louis Barthou, sent a special letter to the head of occupation forces in Istanbul to warn him of communist propaganda directed at the 1921 class of the military draft and the communist presence in Istanbul. ${ }^{39}$

Indeed, some French draftees tried to enlist specifically to be sent to Istanbul to undertake this defeatist communist work. A case in point is Dieudonné Soulié, a French communist who volunteered to go to Istanbul after being sentenced to two months of prison 
for his anti-militaristic activity in France. According to his account, he undertook to publish a make-do communist paper called Le Cinq Centième (namesake of his unit) in his regiment in Istanbul. His superiors caught him after he had published two issues. ${ }^{40}$ Defeatist propaganda within the troops sent overseas was one of the principal ways the European communist movement lent a helping hand to their colonial comrades. Hence, the anti-militaristic and anti-colonial activities are linked. This was true for Istanbul and was also the case in the Ruhr, Syria, and Morocco. ${ }^{41}$ It is no coincidence that Jacques Doriot was in charge of both the anti-militaristic and colonial sections of the PCF in the $1920 \mathrm{~s}^{42}$

The anti-militaristic efforts of the communists were less of an issue among the British and Italian troops. Yet the local militants did their best to address them and occasionally found a welcoming attitude. They had access to both Italian- and English-language defeatist propaganda material. ${ }^{43}$ The English material included a flyer called The Shame of Being a Scab. ${ }^{44}$ While it sounds like a text addressing striking workers or potential blacklegs, further digging proves otherwise. The flyer was signed by Lenin and Tchitcherine, and was initially written for the British and American soldiers at the Arkhangelsk front in Russia. Although Istanbul presented a different context, the militants smuggling and using it must have thought that its words: "You are the tools of our mutual enemies - the capitalists. You hold the rifles, you work the guns with which to shoots us-your fellow workers [. . .]. Comrades! Drop this dirty work. Turn your guns on your real enemies, the sweaters [sic] and capitalists," would apply equally well to the context of British soldiers in occupied Istanbul. ${ }^{45}$

It seems that there were some receptive soldiers within the British troops. Odette Keun, a Dutch militant who was deported from Istanbul by the British, reported the amicable attitude of British navy sailors to the communist prisoners. According to her account, the sailors addressed her as "Bolshevist girl" and lent her and the other communist prisoners a helping hand. ${ }^{46}$ Communist British sailors made another appearance in Istanbul while protecting a clandestine communist meeting where a special Comintern representative from France delivered the keynote. ${ }^{47}$

Several hundreds of North African and South Asian soldiers were stationed in occupied Istanbul, within the ranks of the French and British armies, respectively. Their presence in Istanbul permitted the Comintern to act upon their commitment to support revolutionary nationalist movements in the colonial East that they had solemnly declared on occasions like the Baku Congress. ${ }^{48}$ One particular mission involved an Arab communist known as Hassan the Arab, Ishan Sadoulin, a Tatar communist veteran coming to the city after two successful propaganda missions in Azerbaijan and Iran, and several Azerbaijani-Tatar militants. ${ }^{49}$ These militants seized every opportunity to meet with North African soldiers in the coffeeshops. A revolution of the Muslim people in India, Egypt, and Iran was imminent, so they stressed in these talks, and the Bolshevists would support it. ${ }^{50}$ The local militants also made good use of the first (and short-lived) Arabic communist daily, Habib al-Umma, published in Tunisia. ${ }^{51}$ The unexpected presence of this Tunisian paper in Istanbul will be dealt with in the next section. 
With the same purpose, flyers in English, Italian, French, and Hindi were smuggled in big loaves of bread from the Soviet Russia. One Turkish communist, Vanlı Kazım, even volunteered in the British army (using his Serbian passport) to disseminate Hindi-language flyers to the Indian soldiers before being discovered. ${ }^{52}$ While direct results of the defeatist Cominternian efforts are hard to gauge, the letters of the colonial soldiers sometimes showed sympathy towards the Turkish National Liberation War. ${ }^{53}$

\section{Sailors as a Communist Hyphen}

Recalling the sailors crowding La Sirène and, more importantly, the UIT local down the street, helps us make a point, long overdue, for Comintern history. The role of anonymous sailors as the agents of transnational political ties has received some interest. ${ }^{54}$ However, notwithstanding the Comintern efforts to establish transnational connections by mobilising rank-and-file sailors, the part of this collective actor in the Comintern history has never been the subject of any serious study.

The communist papers smuggled by sailors in La Sirène were a quintessential part of the transnational communist scene of the city. The identity of the sailors doing the footwork remains unknown, but in other cases it is possible to get a glimpse of the sailors who connected Istanbul to the broader communist movement. Such is the case for four French sailors from the ship Sahara, operating on the Marseille-Istanbul-Batumi line. The leader of this group of sailors, Jean Carrière, seemed as reluctant as his fellow sailors about admitting his communist militancy after their arrest. Yet his membership card to the Marseille section of the PCF along with hidden communist literature in French, Turkish, Russian, and Georgian languages found in his possession told otherwise. ${ }^{55}$ Other sailors admitted that a young polyglot Armenian communist named Victor Aboyantz provided them with the papers and flyers. ${ }^{56}$ Victor Aboyantz also appears in the Italian archives within a Batumi communist mission, in charge of contacting merchant sailors in the Black Sea port of Batumi, most notably the French and Italian ones. ${ }^{57}$ Similarly, a French report in 1921 indicates that the Italian merchant ships regularly transported communist propaganda material between North Africa and Istanbul. ${ }^{58}$ This link might explain the presence of Tunisian communist papers in Istanbul.

There was also a spontaneous element concerning the sailors' role in Istanbul. UIT-affiliated sailors imported communist literature from Novorossiysk and Batumi despite, and not because of, the directives of the UIT leadership. ${ }^{59}$ According to Tahir Illyasi, a Sharia court judge from Oufa, at the beginning of his aid mission trip to Istanbul to collect donations for the famine-struck Soviet Muslims, he was quarantined on board a ship from Odesa to Istanbul by the Interallied authorities for carrying an unrecognised Soviet passport. He could only land in Istanbul with the help of a Turkish-speaking Greek sailor-a Bolshevik sympathiser. Yet İlyasi explains that this clandestine helping hand came not as a result of an elaborate scheme by any particular organisation, but an act of sympathy from one sailor, who took a liking to the Bolsheviks, "because the British hated them the most." 
The Comintern made elaborate efforts, too. Istanbul was part of, or even the centre of, several Comintern projects to establish maritime connections. Istanbuli communists tied their political activity to the Comintern centre and the Caucasian centre of the Communist Party of Turkey (CPT) through these connections. Batumi was the primary node in this network. Several factors explain its prominent position. Even after the Bolshevisation of Georgia, Bolshevik power encouraged naval trade through Batumi. The economic benefits in a dire period were the main reason. But it also helped the Comintern to use Batumi as a hub, much like the Dashnak did a few decades earlier. ${ }^{61}$ Helpful too was the mighty and zealously Bolshevik (even before Sovietisation) Sailors' Union in Batumi, which made sure that no European ship left the town without a fellow union man aboard. ${ }^{62}$

The CPT installed a Batumi chapter to capitalise on these conditions and moved its Organisation Bureau there. ${ }^{63}$ This chapter included a young Nazım Hikmet as a candidate party member. ${ }^{64}$ It counted no less than twenty-five members, a respectable number for the diaspora of a communist party created a few months prior and just beginning to organise in its home country. ${ }^{65}$ İsmail Kadri, the Batumi representative of the CPT, boasted in a letter to Lenin and Zinoviev in 1921 that this Batumi Bureau has already sent numerous comrades to Istanbul. They were also sending communist literature to Istanbul and Anatolia and operating an underground apparatus to transfer militants. ${ }^{66}$ The occupation authorities confirm the efficacy of the work of the Batumi apparatus, complaining that militants with forged Iranian passports provided in Batumi kept showing up in Istanbul. ${ }^{67}$ The operation seems to have been in sync with what Roland Ginzberg, a Jewish leader of the UIT, wrote to the ECCI from Istanbul. After proposing the establishment of a centre in Batumi to benefit from the naval connections, he suggested that "communication and transportation between Batumi and Istanbul should be provided by comrades working on ships that regularly make these trips. $" 68$

Voices of those who concocted the scheme are easier to discern than those who enacted it. Yet it is possible to gather the bits and pieces scattered over the documentation left by the militants and those who policed them. Among a scene dominated mostly by Greek, Georgian, Italian, and French sailors, a rare Turkish name appears as a critical link between the Istanbul communist scene and Soviet ports. French forces mention a captain named Mehmet working on the French ship Jean, who collaborated with Hüseyin Sait Bey from the IKG (İstanbul Komünist Grubu, or Communist Group of Istanbul). Mehmet's work brought him to Soviet ports, and he duly transmitted material from these ports to Hüseyin Sait Bey and through him to the Istanbul communist scene. ${ }^{69}$ Ginzberg's letter to the ECCI gives us some other clues. Although he provides no details regarding the "comrades working on ships," the UIT was a predominantly Greek organisation, and connections with Batumi must have involved Greek communist sailors. Add the French communist sailors of the Sahara or the Italian sailors linking Tunis to Istanbul and we see an incomplete but instructive picture of the multinational body of communist sailors crisscrossing the Black Sea and the Mediterranean. This "motley crowd" ${ }^{70}$ working around Istanbul proves that French concerns about the growing communist influence within the merchant ships were, in all likelihood, well founded. ${ }^{71}$ 


\section{Cominternian Network-Making in Istanbul}

The provenance of communist publications present in Istanbul tells us quite a bit about the local communists' connections. Providing an exhaustive list of the publications circulating in the city is almost impossible given that their distribution was often banned by the authorities and organised in the strictest secrecy. However, police accounts of publications seized in the city and statements or reports by local communists show that communist publications in at least fifteen languages ${ }^{72}$ circulated in Istanbul between 1920 and $1923 .^{73}$

Some of the languages and publications involved likely did not have a regular presence in the city, but were either used for specific goals or simply brought by travellers passing by. Hindi-language flyers might be an example of the former. Three issues of a Lithuanian communist paper seized by the French police on board the Corvin could be an example of the latter. However, even this qualification should be qualified. In the case of the Hindi materials, numerous Indian Comintern militants were based in Baku, along with the members of the CPT and the Communist Party of Iran. ${ }^{74}$ Two parts of this triangle, the Iranian and Indian communists, collaborated and utilised an elaborate scheme of smuggling material from Mumbai to Bender Abbas and Bender Bushehr. ${ }^{75}$ Therefore Baku could have provided a more or less regular stream of Hindi-language publications to Istanbul, together with the newspapers and brochures published by the CPT centre in the town. In the latter case, it seems unlikely that the Lithuanian-speaking community in Istanbul could be populous enough to make it viable to publish or regularly import a communist paper in this language. Yet the passport department in Istanbul had registered objections to giving passports to a surprisingly large number of Baltic citizens in Istanbul to leave the city, due to their Bolshevik connections - perhaps giving an idea about the audience of the Lithuanian publications found in Corvin. ${ }^{76}$

In the communist literary scene of the city, not all languages had the same weight. French stood out, serving as a lingua-franca for the Istanbuli communists. More than just an oddity of the internationalist political milieu, the omnipresence of French throughout Istanbul surprised some contemporaries. Magdeleine Marx noted, now without a touch of exaggeration, how "French [was] almost as common as Turkish in Istanbul." $" 77$ A steady influx of communist publications in French, both original writings of French Marxists and translations from the works of Soviet leaders, consolidated its pervasiveness. The presence of a French communist cluster in Odesa in contact with Istanbul through the Southern Bureau must have helped. ${ }^{78}$ The memoirs of one strikingly apolitical Turkish resident of occupied Istanbul illustrate how readily available French communist literature was. He describes how he had decided to translate a French text as a language learning practice. He choose the writings of Lenin that were "coming to Darulfünün [University of Istanbul] from Moscow as brochures in French," not for any sympathy towards the communist cause, but because they were handily available. ${ }^{79}$ Although it is impossible to know which particular works of Lenin he was translating, other French-language sources in circulation left a clear paper trail. 
On one ship, the Corvin, arriving in Istanbul from Batumi in November 1921, French authorities seized a 154-piece collection of communist propaganda material. Its contents were wide-ranging, from a leaflet about the creation of the Romanian communist group in the Romanian language to "Class struggle and dictatorship of the proletariat" in German by Bela Szanto, a cabinet member of the short-lived Hungarian Soviet Republic. A sizeable chunk of this material was composed of French brochures. In addition to translations from Lenin, Trotsky, and Zinoviev, there were also original works by Henri Guillebaux and Pierre Pascal. ${ }^{80}$ Although the French authorities were able to intercept these brochures before they reached the hands of local communists, it is clear that others passed the control points unnoticed. Turkish and Greek translations of Charles Rappoport's Précis du Communisme circulated in Istanbul, as a supplement to the UIT newspaper Neos Anthropos (New Human). ${ }^{81}$

Despite interdiction by French occupation forces, l'Humanité, the French-language daily of the PCF, enjoyed an extensive distribution network in Istanbul. ${ }^{82}$ Roland Ginzberg reported to the ECCI that the union had sold nine hundred issues of l'Humanite $^{83}$ The wide-ranging presence of the French communist paper benefitted some Istanbuli communists in unexpected ways. After his escape from Ankara, Salih Hacıoglu - leader of the Ankara-based communist organisation THIF (Türkiye Halk İştirakiyun Fırkası, the People's Communist Party of Turkey) and a future victim of Stalinist purges - wandered the streets of Istanbul as a political outlaw on the run. In a moment of serendipity, Hacioğlu came across a man reading l'Humanité. Hacioğlu took a leap of faith and greeted this stranger by saying, "Bonjour camarade." The camarade in question, a French communist, agreed to shelter the fugitive. ${ }^{84}$

The reach of l'Humanité went beyond the communist milieu of Istanbul. A l'Humanité article about the postwar status of Turkey went viral in Istanbul in $1919,{ }^{85}$ when the paper was still operating under a socialist editorial board. Hakimiyet-i Milliye (National Sovereignty), the semiofficial mouthpiece of the Ankara government, ran translations of articles from l'Humanité, one regarding the bloodshed committed by the French in Syria. ${ }^{86}$ This editorial choice and the easy access of Turkish nationalists to the French communist paper very much upset the French occupation authorities, leading them to order a search for copies of l'Humanité in Istanbul. ${ }^{87}$

At least one hundred copies of the Communist Party of Bulgaria's Turkish newspaper reached Istanbul, ${ }^{88}$ along with two hundred copies of its Bulgarian paper. ${ }^{89}$ Beyond what these numbers reveal, Istanbuli communists, and most notably the İKG, had a privileged relationship with the CPB. This connection is no surprise. First of all, Bulgarian militants are numbered among the pioneers of the Ottoman socialist movement, including some of the first socialist deputies in the Ottoman parliament. ${ }^{90}$ Secondly, the CPB ranked among the most powerful sections of the Comintern until its failed uprising in the fall of 1923, and in 1922 Trotsky estimated that it was the only communist party who controlled the majority of its country's working class. ${ }^{91}$ Admittedly, the number of CPB-originated publications arriving in Istanbul seems less than impressive. However, the letters of Şefik Hüsnü, the leader of the IKGG, show that there was more to it than that. IKG readily deployed the CPB's logistical capacities, most notably its printing press with an 
Arabic-Ottoman typeface and its Turkish-speaking militant base. In the absence of their own printing press, a sizeable part of IKG's brochures and newspapers were published in Sofia and then smuggled to Istanbul. ${ }^{92}$

It is also clear that the Balkan communists in Istanbul, themselves involved in an ongoing process to create a unified Balkan communist organisation, were well-connected to the city's other communist organisations. One such connection, between the UIT and Balkan communism, surfaced when the British police arrested the UIT leader Seraphim Maximos in late 1921. Maximos spent seventy days in British prisons after they found him in possession of the stamp of the UIT and a private letter from the "British Red Trade Unions. ${ }^{" 93}$ But more intriguingly, at the time of his arrest Maximos was in the company of a certain Nikolai Traitcheff, whom the French Sûreté had named among the few "very dangerous" Bolsheviks in Istanbul, as the "representative of Bulgarian communism in Istanbul." Traitcheff out as spreading communist propaganda and stashing flyers and weaponry in his shop. ${ }^{95} \mathrm{He}$ also had direct ties with the Southern Bureau of the Communist International. A paper from this bureau's archives, probably written for the use of a Comintern courier, includes the address of Traitcheff's shop in Istanbul with a note in Russian that reads "only talk to the comrade Nikolai Traitcheff himself." 96

İKG leader Şefik Hüsnü took great care in consolidating his organisation's ties with the CPB. The results are less than clear, but he did demand a short-term internship for some of his propagandists within the $\mathrm{CPB}$ ranks. ${ }^{97} \mathrm{He}$ travelled to Sofia, addressing both the CPB Congress and a meeting for the Turkish-speaking CPB members. ${ }^{98}$ Traitcheff was likely the intermediary in this Bulgaria-Istanbul connection, as Şefik Hüsnü mentioned Traitcheff several times in his reports. ${ }^{99}$ In one of these reports, he noted that Traitcheff indeed introduced Maximos to the CPB, showing that there was a pattern.

The Balkan Communist Group, initially led by a Bulgarian militant and then by Aron Bega, a Jewish-Romanian militant, was reportedly in talks with a Turkish communist group, possibly the IKG, for joint action in Istanbul. ${ }^{100}$ The high number of Serbian, Romanian, Bulgarian, and Hungarian ${ }^{101}$ communists in Istanbul listed as dangerous Bolsheviks confirms the importance of Balkan communism in the transnational Istanbul communist scene. ${ }^{102}$

In the same vein, other publications in Istanbul testify to the ongoing relations among left-wing militants who once shared the common Ottoman space. The Greek-language publication of the $\operatorname{SEKE}(\mathrm{K})$, the predecessor of the Greek Communist Party (KKE), found a broad audience in Istanbul, thanks to the Greek-speaking base of the UIT. ${ }^{103}$ The same party also published a Turkish-language newspaper, Yeni Ziya (The New Light), printed in Thessaloniki. However, its circulation in Istanbul remained limited in comparison to its quasi-namesake and Bulgarian counterpart, mentioned earlier. ${ }^{104}$

Unsurprisingly, the Armenian communists formed an essential part of the post-Ottoman revolutionary scene. Armenian revolutionaries played a crucial role in connecting the radical spaces of Istanbul, the Caucasus, Iran, and even France, even in the early 1900s. ${ }^{105}$ These well-established networks were instrumental in the formation of communist organisations throughout the Middle East. ${ }^{106}$ According to one ex-Cheka member, a mission of 
approximately forty Armenian communists linked Batumi with Marseille, Italian ports, and Istanbul. Among them, a certain Surien worked as the special courier for the Caucasian centre of the CPT and transported French and Turkish material to Istanbul. ${ }^{107}$

Caucasia-based Armenian militants travelled to Istanbul to proselytise the communist cause. One of them, Artemis Gasparian, played a leading role in the May Day 1922 demonstration in Istanbul, taking place under the aegis of a communist-socialist coalition. ${ }^{108}$ The arrest of another Armenian communist in Istanbul reveals an emblematic picture of the Armenian revolutionaries' transnational world. Vargarchak Boudakian was born in Cairo in 1889. He eventually moved to Caucasia with his brother. In 1921, the Dashnak Party executed his brother, "a notorious communist," in Erevan. In 1922, Vargarchak boarded the Italian ship Aldo, leaving Batumi for Istanbul. He was apprehended upon his arrival in Istanbul with Armenian and Turkish communist flyers as well as a forged Iranian passport in his possession. ${ }^{109}$

In addition to the roving Armenian revolutionaries, local Armenian communists also constituted a crucial part of the Istanbuli communist scene. The Eastern Section of the Comintern listed a local communist-leaning Hunchakian chapter as one of the three Istanbuli constituents of the future Unified Communist Party of Turkey-along with the UIT and İKG. ${ }^{110}$ However, I could find scant evidence about their activity other than the Yerguir (Country) newspaper they published. ${ }^{111}$

The mission of Hassan the Arab and the Tatar communist Sadoulin mentioned above, shows another aspect of post-Ottoman connections coming in handy for Comintern operatives - and not just in intra-Communist settings. French sources note, not without anxiety, Hassan's frequent contacts with the Faisalist Arabic circles in Istanbul. ${ }^{112}$ Emir (and eventually King) Faisal, the epitome of a British-backed figurehead, is admittedly not the most obvious candidate for a Comintern ally. ${ }^{113}$ However, for the better part of the 1920s, the Comintern sought to forge alliances with national liberation movements in the Middle East. Thus an effort by the Cominternians for exploratory talks with Faisal's forces (he was called "an exponent of an embryonic perception of pan-Arab nationalism" in his Syria days by one author) would fit perfectly with this orientation. ${ }^{114}$

Moreover, Hassan, an ex-Ottoman officer himself, was also in contact with a certain Ali Bey, an Ottoman officer. An ex-partisan of the Union and Progress Committee and now a "Millici," that is to say, a militant of the National Liberation fight, Ali Bey reportedly linked the Comintern to the Ankara government. ${ }^{115}$ The collaboration with the Comintern in the Turkish National Liberation War became most visible through the trains full of weaponry sent from Russia to Turkey. ${ }^{116}$ It also had a less apparent side, on a much-limited scale, visible in Istanbul. Local communists helped the nationalists smuggle weapons stolen from different Istanbul arsenals to Ankara. The French Sûreté reported that this link, created through one active and one former Ottoman officer, was instrumental in this concrete form of collaboration: Ali Bey, a naval officer, helped the communists establish connections to import propaganda material from Crimea to Istanbul and the communists took part in the smuggling operation. ${ }^{117}$

The case of a certain Mehmet ${ }^{118}$ gives us a further indication of how the same people smuggled communist propaganda material to Istanbul and weapons from Istanbul to 
Anatolia. The sailor Mehmet, who was "once arrested for being a porter of Bolshevik flyers," reappeared as one of the organisers of two big weapon heists to support the National Liberation War. ${ }^{119}$ The case of Vanlı Kazım also illustrates this collaboration. After the British authorities got wind of his role disseminating Hindi-language defeatist propaganda within the British armies, he saw no option but to leave Istanbul. The nationalist sailors - with whom he had collaborated on the distribution of propaganda material within the occupation armies - undertook the organisation of his forced travel from Istanbul to Soviet soil. ${ }^{120}$ In the same vein, the future leader of the CPT, Ismail Bilen, later recalled how he cut his political teeth in these weapon-smuggling operations from Istanbul as a young sailor, without party affiliation but "with consciousness."121

While the communists of Istanbul enjoyed long-standing connections, they also forged new ones. Unlike, for instance, their Iranian counterparts, leading communists in Istanbul had no prior ties with the Russian Social Democracy-turned-communism, now at the very forefront of global radical politics. Although several attempts were made to establish links, what connected Istanbul to Bolshevik politics most directly came from an unexpected turn of the Russian Civil War. In the last months of 1920, the defeated white armies of Pyotr Wrangel had to evacuate Crimea, and their French allies hastily shipped them to Istanbul. ${ }^{122}$ While internal problems began to erode Wrangel's forces, the Bolsheviks made it a priority to deliver the coup de grace. An Istanbul Section of Russian Communist Party (Bolshevik) was established with the goal of dismantling the Wrangel army. The minutes of its meetings show that they hoped to "turn the Wrangel Army into a Red Army." 123 The French police got wind of their activity and cut it short with simultaneous raids on a committee meeting and its leaders' houses. They discovered a make-do printing machine, encrypted letters, propaganda material, and two party seals hidden in a cigar box. ${ }^{124}$ Fifteen militants ended up behind bars, fourteen of them charged with producing "Bolshevik propaganda.",125

Until its dismantling, this committee served as a meeting point for different organisations. Its secretary, Kolbanovsky, utilised diverse initiatives to achieve that. One clandestine meeting in Istanbul brought two British, one French, one Greek, and two Turkish militants together with the Bolshevik Party members to form a United Committee of the Communist Party. ${ }^{126}$

\section{Conclusion}

Communist sailors carried papers, rumours, and experiences of faraway ports - be it Tunis, Marseille, or Batumi-to Istanbul, and became instrumental in inserting the former imperial capital into global communist networks. Soldiers from Europe and the colonial world brought their existing networks and connections to the city. Istanbul's story provides us with an example, underlining the role of these rank-and-file militants in the history of the Communist International in particular and international communism in general.

Istanbul's imperial background and linguistic richness created a fertile ground for Cominternian network-making. Bulgarian-, Arabic-, and Armenian-speaking militants 
with an Ottoman background both interacted with one another in Istanbul and used their linguistic skills to facilitate connections between the revolutionary movements of other lands. Through the agency of this multinational body of militants, communist papers, ideas, and experience from Europe, the Middle East, the Balkans, and Caucasia circulated - not so freely - in Istanbul.

The case of Istanbul is noteworthy in that several historical conditions aligned to gather a variety of communist actors in one space and make the city a crucial communist hub. Allied troops brought echoes of the post-World War I veteran/soldier's left-wing activism to the city. Colonial soldiers arriving in the city within the ranks of these same armies made Istanbul suitable ground for flexing the anti-colonial muscle of the Comintern. Istanbul's position as a vital maritime node between Mediterranean Europe, the Middle East, and Russia was further consolidated and acquired a whole other meaning with the establishment of the Soviet state. Communist sailors from different parts of this triangle created the conditions for a vibrant circulation of communist material in and around Istanbul. The demise of the empire was underway, but its multiethnic and multireligious background rendered Istanbul a fertile ground for Comintern network-making. Turkish communists of the city experienced the period of occupation in the context of the National Liberation War waged on Anatolia and ensuing civil war. They joined the networks of international communism in Istanbul but also established an uneasy relationship with the militants of the Ankara government to create yet another axis of communist activism.

By the end of the timespan covered in this article, the Ottoman Empire was no more; but many links forged during the Ottoman realm persisted. Emerging national borders in the old Ottoman territory transnationalised - and complicated - what were hitherto intra-imperial connections, but did not put an end to them. The perspective of Istanbul reveals much about the links around the western parts of the former empire. Changing our study area to Mersin or Damascus would more clearly display the continuity of the ties with the Arab East. Nonetheless, Istanbul is a particularly apt example, revealing that the demise of the Ottoman Empire and the surge of national states and their borders did not stop the citizens of new national entities moving across borders and constructing a transnational radical space. It shows, in effect, the interconnected world of communists in its micro-cosmos.

\section{Bibliography}

\section{Unpublished Primary Sources}

AD: Archives Diplomatiques, Paris (La Courneuve)

- Serie K, Carton 102

ASMSAC: Archivio Storico del Museo Storico dell'Arma dei Carabinieri, Rome

- Busta 388

- Busta 394

PANDOR: Portail Archives Numériques et Données de la Recherche

- Fonds de la direction du Parti Communiste Français (1922-1939).

RGASPI: Russian State Archive of Socio-Political History, Moscow

- Opis 495/18 (Secretariat of the Executive Committee of the Communist International) 
- Opis 495/84 (Communist Party of Syria)

- Opis 495/85 (Communist Party of Egypt)

- Opis 495/154 (Eastern Section of the Communist International)

- Opis 495/266 (Personal Files-Turkey)

- Opis 502 (Southern Bureau of the Communist International)

SHD: Sérvice Historique de la Défense, Paris (Vincennes)

- GR $7 \mathrm{~N}$

- GR $20 \mathrm{~N}$

TNA: The National Archives, London (Kew)

- FO (Foreign Office) 371

TÜSTAV: Türkiye Sosyal Tarih Araştırma Vakfı Arşivler, İstanbul

- CD 19

University of Washington Libraries

- Special Collections Broussais C. Beck Papers

\section{Cited Periodicals}

L'Humanité (Paris), 1921

Inprecor (Berlin), 1922

\section{Published Primary Sources}

Akbulut, Erden, ed. Milli Azadlık Savaşı Anıları. İstanbul: TÜSTAV, 2006.

Akbulut, Erden, and Mete Tunçay, eds. Beynelmilel Isşçiler İttihadı. İstanbul: İletişim Yayınları, 2016.

— Volume. İstanbul: Sosyal Tarih Yayınları, 2012.

—_ eds. Türkiye Halk İștirakiyun Fırkası, 1920-1923. İstanbul: İletişim Yayınları, 2016.

Hikmet, Nazım. Yaşamak Güzel Şey Be Kardeşim. İstanbul: Yapı Kredi Yayınları, 2019.

İlyasi, Tahir. Ístanbul Hatıratı 1922. İstanbul: Kırmızı Kedi Yayınevi, 2019.

Keun, Odette. Sous Lénine: Notes d'une Femme Déportée en Russie par les Anglais. Paris: Flammarion, 1922.

Marty, André. La Révolte de la Mer Noire (1918-1919). Paris: Editions Sociales Internationales, 1939.

Marx, Magdeleine. La Perfide, par Les Routes d'Asie Mineure. Paris: Flammarion, 1925.

Persidskiy Front Mirovoy Revolutsii: Dokumenty o Sovetskom Vtorjenii v Gilyan (1920-1921). Moscow: Kvadriga, 2017.

Riddell, John, ed. To See the Dawn: Baku, 1920_First Congress of the Peoples of the East. New York: Pathfinder Books, 1993.

Sunata, İ. Hakkı. İstanbul'da İşgal Yılları. İstanbul: Türkiye İş Bankası Kültür Yayınları, 2006.

\section{Secondary Sources}

Akıncı, Turan. İsgal: İstanbul'da Yabancı Güçler. 1stanbul: Remzi Kitabevi, 2020.

Alexanderson, Kris. Subversive Seas: Anti-Colonial Networks across the Twentieth-Century Dutch Empire. New York: Cambridge University Press, 2019.

Allawi, Ali A. Faisal I of Iraq. London: Yale University Press, 2014.

Bakar, Bülent. Esir Şehrin Misafirleri: Beyaz Ruslar. Istanbul: Tarihçi Kitabevi, 2012.

Berberian, Houri. Roving Revolutionaries: Armenians and the Connected Revolutions in the Russian, Iranian, and Ottoman Worlds. Oakland: University of California Press, 2019.

Broué, Pierre. Histoire de l'Internationale Communiste. Paris: Fayard, 1997.

—. Rakovsky ou la Révolution dans tous les Pays. Paris: Fayard, 1996.

Carr, Edward Hallett. Twilight of the Comintern, 1930-1935. New York: Pantheon Books, 1983. 
Chaqueri, Cosroe. The Soviet Socialist Republic of Iran, 1920-1921: Birth of the Trauma. Pittsburgh: University of Pittsburgh Press, 1995.

Chuzeville, Julien. Un Court Moment Révolutionnaire: La Création du Parti Communiste en France. Paris: Libertalia, 2017.

Criss, Nur Bilge. Istanbul under Allied Occupation, 1918-1923. Boston: Brill, 2000.

Erdem, Hamit. Osmanlı Sosyalist Fırkası ve İștirakçi Hilmi. İstanbul: Sel, 2012.

Foster, William Z. History of the Three Internationals: The World Socialist and Communist Movements from 1848 to the Present. New York: Greenwood Press, 1968.

Francescangeli, Eros. Arditi del popolo. Argo Secondari e la Prima Organizzazione Antifascista (1917-1922). Roma: Odrarek, 2000.

Fuhrmann, Malte. Port Cities of the Eastern Mediterranean: Urban Culture in the Late Ottoman Empire. Cambridge: Cambridge University Press, 2020.

Goebel, Michael. Anti-Imperial Metropolis: Interwar Paris and the Seeds of Third World Nationalism. Cambridge: Cambridge University Press, 2015.

Hajek, Milos. Storia dell' Internazionale comunista (1921-1935): la politica del fronte unico. Rome: Editori Riuniti, 1975.

Hallas, Duncan. The Comintern. Chicago: Haymarket Books, 2008.

James, C. L. R. World Revolution 1917-1936: The Rise and Fall of the Communist International. Westport: Hyperion Press, 1973.

Jenkins, Jennifer, Heike Liebau, and Larissa Schmid. "Transnationalism and Insurrection: Independence Committees, Anti-Colonial Networks, and Germany's Global War." Journal of Global History 15:1 (2020): 61-79.

Keleş, Muhammet. "Şems Gazetesi ve İstanbul'daki İranlılar." Tarih Araştırmaları Dergisi 39:64 (2020): 443-53.

Kousoulas, D. George. Revolution and Defeat: The Story of the Greek Communist Party. London: Oxford University Press, 1965.

Linebaugh, Peter, and Marcus Rediker. The Many-Headed Hydra: Sailors, Slaves, Commoners, and the Hidden History of the Revolutionary Atlantic. Boston: Beacon Press, 2013.

MacArthur-Seal, Daniel-Joseph. " Intoxication and Imperialism: Nightlife in Occupied Istanbul, 1918-23." Comparative Studies of South Asia, Africa and the Middle East 37:2 (2017): 299-313.

Mango, Andrew. Atatürk : The Biography of the Founder of the Modern Turkey. Woodstock, New York: The Overlook Press. 2002.

Marie, Jean-Jacques. Histoire de la Guerre Civile Russe: 1917-1922. Paris: Editions Tallandier, 2015.

Marty, André. Fraternisation, Esquisse Historique de la Tradition du Prolétariat Français. Paris: Librairie de l'Humanité, 1925.

Masalha, Nur. "Faisal's Pan-Arabism, 1921-33." Middle Eastern Studies 27:4 (1991): 679-93.

Minassian, Taline Ter. Colporteurs du Komintern. L'Union Soviétique et les Minorités au Moyen-Orient. Paris: Les Presses de Sciences Po, 1997.

Natoli, Claudio. La Terza Internazionale e il Fascismo, 1919-1923: Proletariato di Fabbrica e Reazione Industriale nel Primo Dopoguerra. Rome: Editori Riuniti, 1982.

Panteleev, Mihail, and Grigorij Evseevič Zinov'ev. Agenty Kominterna: Soldaty Mirovoj Revolutsii. Moscow: ÉKSMO, 2005.

Pons, Silvio. La Rivoluzione Globale: Storia del Comunismo Internazionale, 1917-1991. Turin: Einaudi, 2012.

Provence, Michale. The Last Ottoman Generation and the Making of the Modern Middle East. Cambridge: Cambridge University Press, 2018.

Raza, Ali, and Benjamin Zachariah. "To Take Arms across a Sea of Trouble: The 'Lascar System,' Politics, and Agency in the 1920s." Itinerario 36:3 (2012): 19-38.

Roy, Samaren. M. N. Roy: A Political Biography. New Delhi: Orient Longman, 1997. 
Stevens, Margaret. Red International and Black Caribbean: Communists in New York City, Mexico and the West Indies, 1919-1939. London: Pluto Press, 2017.

Streets-Salter, Heater. World War One in Southeast Asia: Colonialism and Anticolonialism in an Era of Global Conflict. Cambridge: Cambridge University Press, 2017.

Studer, Brigitte. The Transnational World of the Cominternians. Houndmills: Palgrave Macmillan, 2015.

Şenış1k, Pınar. "The Allied Occupation of Istanbul and the Construction of Turkish National Identity in the Early Twentieth Century." Nationalities Papers 46:3 (2018): 501-13.

Tichelman, Fritjof. Henk Sneevliet. Montreuil-sous-bois: La Brèche, 1988.

Totaro, Cesario, and Antonio Bagnaia. Missione Caprini: il Contributo dell'Arma dei Carabinieri per il Riordino della Gendarmeria Ottomana. Turin: Pintore, 2005.

Ülker, Erol. Mütareke'nin Illk Yıllarında İstanbul'da Direniş ve Sol: 1918-1920. Istanbul: Sosyal Tarih Yayınları, 2020.

Wolikow, Serge. Histoire de l'Internationale Communiste. Paris: Editions de l'Atelier, 2010.

Yalimov, Ibrahim. "The Bulgarian Community and the Development of the Socialist Movement in the Ottoman Empire During the Period 1876-1923." In Socialism and Nationalism in the Ottoman Empire 1876-1923, edited by Mete Tunçay and Erik Jan Zürcher. London: British Academic Press, 1994.

Yerasimos, Stefanos. Türk-Sovyet ilişkileri: Ekim Devriminden "Millî Mücadele” ye. Ankara: Gözlem Yayınları, 1979.

\section{Notes}

* Burak Sayım is a $\mathrm{PhD}$ candidate at the International History Department of the Graduate Institute of International and Development Studies, Geneva. His dissertation project, "Transnational Communist Networks in the Post-WWI Middle East: Anti-Colonialism, Internationalism and Itinerant Militancy," focuses on communist militancy in the Middle East between 1919 and 1928.

1 Goebel, Anti-Imperial Metropolis, 176.

2 James, World Revolution.

3 Foster, History of the Three Internationals.

4 Carr, Twilight of the Comintern.

5 Hallas, The Comintern.

6 Broué, Histoire de l'Internationale Communiste.

7 Wolikow, Histoire de l'Internationale Communiste.

8 Pons, La Rivoluzione Globale.

9 Respectively Natoli, La Terza Internazionale; and Hajek, Storia dell' Internazionale comunista.

10 Stevens, Red International and Black Caribbean.

11 Among others, Roy, M. N. Roy: $A$ Political Biography; Tichelman, Henk Sneevliet; Broué, Rakovsky ou la
Révolution; Panteleev and Zinov'ev, Agenty Kominterna.

12 Studer, The Transnational World.

13 See Erdem, Osmanlı Sosyalist Firkası.

14 For a notable exception, see; Ülker, Mütareke'nin Illk Yillarında.

15 See Fuhrmann, Port Cities; for Iranian Constitutionalists in Istanbul see Keleş, "Şems Gazetesi"; as a part of Armenian revolutionary networks see Berberian, Roving Revolutionaries; for the role of its schools in the formaiton of the elites of different post-Ottoman states, Provence, The Last Ottoman Generation, 9-48.

16 SHD, Untitled report, 14 February 1922, Bolchevisme Juin 1921-Juillet 1922, GR 20 N 1106.

17 RGASPI, "Proekt organizatsii Blizhnevostochnogo Bujro v Salonikah," 495/154/222.

18 Francescangeli, Arditi del Popolo; Chuzeville, Un Court Moment Révolutionnaire, 1689; Kousoulas, Revolution and Defeat, 10-1.

19 During the period covered in this article, the Ottoman state was extant in Istanbul from an administrative and legal standpoint. Yet, with the emergence of an 
alternative power center in Ankara and the occupation, Ottoman state's demise was well underway from a political standpoint. Hence, I construe the period of Occupied Istanbul as a transitional one where the post-Ottoman political setting coexisted with the Ottoman state's legal existence. Therefore, in this particular case, I use the expression "post-Ottoman" in this sense, to express this transitional and often complex reality.

20 RGASPI, "Du CC du PCS (SSIC) à la Section Orientale de l'IC," 16 August 1929, 495/84/21/19; RGASPI, Letter from Joseph Rosenthal to Georgiy Safarov, 5 May 1922, 495/85/12/2.

21 See Akıncı, İsgal; Criss, Istanbul; Totaro and Bagnaia, Missione Caprini; Şenışık, The allied occupation; MacArthur-Seal, Intoxication.

22 Mango, Atatürk, 196.

23 Hikmet, Yaşamak Güzel Şey Be Kardeşim, 45.

24 Akbulut, Milli Azadlık Savaşı Anıları, 81.

25 L'Humanité, 4 November 1921; Inprecor, 29 Septeber 1922, "Peace to the Turkish People War to European Imperialism."

26 SHD, Questionnaire about Konstantinopola Esperanta Asocio Byzantio, 25 October 1921, Renseignements 1921, GR 20 N 1103.

27 ASMSAC, "Sommario della Riunione della Commissione di Polizia Interalleata," 15 January 1920, Sedute del Comitato di Controllo dell'Anno 1920, Busta 394.

28 Bakar, Esir Şehrin Misafirleri, 211-3.

29 Marty, La Révolte, 365-7.

$30 \mathrm{Laz}$ is a national or cultural group, based predominantly in the Black Sea region of modern Turkey.

31 For information about this brewery, see SHD, Compte-Rendu, 13 April 1922, Renseignements 1922, GR 20 N 1103; SHD, Compte-Rendu, 18 April 1922, Renseignements 1922, GR 20 N 1103; SHD, Compte-Rendu, 11 May 1922, Renseignements 1922, GR 20 N 1103; SHD, Compte-Rendu, 19 May 1922,
Renseignements 1922, GR $20 \quad \mathrm{~N}$ 1103; SHD, Compte-Rendu, undated, Renseignements 1922, GR 20 N 1103.

32 TNA, "Bolshevik Propaganda amongst foreign seamen," 1 September 1922, Folder 8170 (Northern Russia-1922), FO 371; SHD, Compte-Rendu, 25 July 1922, Renseignements 1922, GR 20 N 1103.

33 SHD, No title, undated, Renseignements 1922, GR 20 N 1103.

34 SHD, Note de Service, 9 May 1922, Renseignements 1922, GR 20 N 1103; SHD, Compte-Rendu, 19 May 1922, Renseignements 1922, GR 20 N 1103; SHD, Rapport, 16 May 1922, Renseignements 1922, GR 20 N 1103.

35 Sunata, Istanbul'da İsgal Yıllarl, 100-1.

36 Marty, La Révolte, 365-7.

37 RGASPI, "B Tretij Dom Sovietov," $1920,502 / 1 / 23 / 148$.

38 For an account of this submarine trip see Marx, La Perfide.

39 SHD, Letter from Louis Barthou to Charles Charpy, 21 April 1921, Bolchevisme Juin 1921-Juillet 1922, GR 20 N 1106.

40 Notice SOULIÉ Dieudonné, Noël, Marius par Jean Sagnes, http://maitronen-ligne.univ-paris1.fr/spip.php?article131529, accessed 30 June 2020.

41 See Marty, Fraternisation.

42 PANDOR, "Plan de Travail Immediat du Comité Directeur," no date, 1924, Comité Directuer, Fonds de la direction du Parti Communiste Français (19221939).

43 Akbulut, Milli Azadlık Savaşı Anıları, 84-6.

44 SHD, "Quelques Brochures de Propagande Communiste Trouvées à Bord du Corvin à Constantinople," 17 November 1921, Renseignements 1921, GR 20 N 1103.

45 University of Washington Libraries, The Shame of Being a Scab, Box 1/1, Accession No. 0155-001, Special Collections, Broussais C. Beck papers.

46 Keun, Sous Lénine, 81.

47 SHD, Procès-Verbal- Alexandrov and Silitch, Bolchevistes et Justice Militaire Folder, GR 20 N 1141. 
48 Before the communists, Germany had taken great pains during the war to address its propaganda to the colonised populations and more particularly soldiers of the Britsh and French Empires. The spectre of German propaganda alarmed the British and French in occupied Istanbul, but its effect in the Istanbuli political scene appears minimal. See SHD, Report on Germanophile propaganda in Istanbul, 8 November 1921, Bolchevisme Juin 1921-Juillet 1922, GR 20 N 1106; Streets-Salter, World War One; Jenkins et al., "Transnationalism."

49 SHD, "Propagande Bolcheviste parmi les Soldats Musulmans des Troupes Allieés à Constantinople," 2 September 1921, Carton 38/4, GR 20 N 1106.

50 SHD, "Relations Turco-communistes de Constantinople avec Angora," 1921, Carton 38/4, GR 20 N 1106.

51 Document cited in this compilation of documents: b27Akbulut and Tunçay, Istanbul, 308.

52 Akbulut, Milli Azadlık Savaşı Anıları, 84-6.

53 SHD, Compte-Rendu, 27 September 1922, Renseignements 1922, GR 20 N 1103.

54 See, among others, Linebaugh and Rediker, The Many-Headed Hydra; Alexanderson, Subversive Seas; Raza and Zachariah, "To Take Arms."

55 SHD, Compte-Rendu, 2 December 1921, Carton 38/4, GR 20 N 1106; SHD, "Procès-Verbal de Lorenti Carriere Grini et Palmieri," 3 December 1921, Carton 38/4, GR 20 N 1106.

56 SHD, Compte-Rendu, 15 December 1921, Carton 38/4, GR 20 N 1106.

57 ASMSAC, Statement of Harutian, 7 April 1922, Busta 388.

58 AD, "Propagande Bolchéviste en Afrique du Nord," 24 November 1921, Afrique 1917-1940, Affaires Musulmans, Bobine 533, Document n. 55.

59 Akbulut and Tunçay, Beynelmilel, 98-9.

60 İlyasi, İstanbul Hattratı, 41-2.

61 Berberian, Roving Revolutionaries, 51.

62 SHD, Compte-Rendu de Renseignement, 21 January 1921, Renseignements 1921, GR $20 \mathrm{~N} 1103$.
63 Akbulut and Tunçay, İstanbul, 89-90.

64 RGASPI, "Registratsionnij List dlja Studentov KUTVa," 495/266/47(1)/ 154-55.

65 TÜSTAV Archives, "Obschego Cherezichajnogo Sobranija Batumskoj Jachejki Komunisticheskoj Partii Turtsii," 2 December 1921, CD 19, Folder 24_36, Document n. 583.

66 Akbulut and Tunçay, İstanbul, 82.

67 For an account of the overall organisation, see ASMSAC, Statement of Harutian, 7 April 1922, Busta 388; for Vargarak Budakian, SHD, Untitled report, 29 March 1922, Renseignements sur Personnes 1922, GR 20 N 1104; for Tahirzade Haydar, b27Akbulut and Tunçay, İstanbul, 94.

68 Cited in b27Akbulut and Tunçay, Beynelmilel, 90.

69 SHD, Untitled report, 17 July 1922, Renseignements sur Personnes 1922, GR 20 N 1104.

$70 \mathrm{I}$ am borrowing the expression from Peter Linebaugh and Marcus Rediker, who, in turn, take it from Karl Marx and Friedrich Engels; Linebaugh and Rediker, The Many-Headed Hydra, 20.

71 SHD, "Renseignements Relatifs à la Sécurité des Troupes Alliées à Constantinople," 18 July 1922, Carton 38/4, GR 20 N 1106.

72 Namely, and in alphabetical order: Arabic, Armenian, Bulgarian, English, French, Georgian, German, Greek, Hindi, Italian, Lithuanian, Romanian, Russian, Spanish, and Turkish.

73 Akbulut and Tunçay, Ístanbul, 120 and 308; Akbulut, Milli Azadlik Savaşı Anıları, 84-6; SHD "Quelques Brochures de Propagande Communiste Trouvées à Bord du Corvin à Constantinople," 17 November 1921, Renseignements 1921, GR 20 N 1103; SHD, Compte-Rendu, 25 July 1922, Renseignements 1922, GR 20 N 1103; Compte-Rendu, 2 December 1921, Bolchevisme-Grève, GR 20 N 1106, SHD.

74 TNA, "Turco-Aral-Bolshevik Activities in the Middle East," 6 January 1921, E 
267, Folder 6342 (Eastern-1921), FO 371.

75 Persidskiy Front Mirovoy Revolutsii, 410-2.

76 Among others, Lithuanians Leonide Runovsky, Valentine Bunovska, and his husband, Simon Indebaum, and Estonians Isai Scher and Rachel Saag; SHD, Incarceration-Passeports Folder, GR $20 \mathrm{~N}$ 1119.

77 L'Humanité, 3 December 1921.

78 RGASPI, Rapport, 502/1/23/502-3.

79 Sunata, İstanbul'da İşgal Yılları, 66-7.

80 SHD, "Quelques Brochures de Propagande Communiste Trouvées à Bord du Corvin à Constantinople," 17 November 1921, Renseignements 1921, GR $20 \mathrm{~N} 1103$.

81 SHD, Compte-Rendu, 7 September 1922, Renseignements 1922, GR $20 \mathrm{~N}$ 1103.

82 L'Humanité, 10 December 1921.

83 b27Akbulut and Tunçay, Beynelmilel, 64.

84 b27Akbulut and Tunçay, Türkiye, 139.

85 Sunata, İstanbul'da İsgal Yilları, 43.

86 SHD, Rapport, 21 December 1920, Bulletin de Renseignements Journaliers de COC 1920, GR 7 N 4141.

87 SHD, Rapport, 20 January 1920, Bulletin de Renseignements Journaliers de COC 1920, GR 7 N 4141.

88 b27Akbulut and Tunçay, İstanbul, 120.

89 b27Akbulut and Tunçay, Beynelmilel, 59.

90 See Yalımov, "The Bulgarian Community."

91 Hajek, Storia dell'Internazionale Comunista, 61.

92 b27Akbulut and Tunçay, Istanbul, 190.

93 Ibid., 191.

94 SHD, "Bolcheviks à Constantinople," 20 June 1921, Carton 38/4, GR 20 N 1106.

95 SHD, Untitled report, 10 August 1921, Renseignements 1921, GR 20 N 1103.

96 RGASPI, Untitled and undated note, $502 / 1 / 23 / 14$.

97 b27Akbulut and Tunçay, Istanbul, 177.

98 Ibid, 183-6.

99 Ibid, 188-95.

100 SHD, "Aperçu sur le Comité Communiste de Constantinople et ses Liaisons," 17
November 1921, Carton 38/4, GR $20 \mathrm{~N}$ 1106.

101 Listed as a part of the Balkan organisation in Istanbul in the quoted report.

102 SHD, "Bolcheviks à Constantinople," 20 June 1921, Carton 38/4, GR 20 N 1106.

103 b27Akbulut and Tunçay, Beynelmilel, 59.

104 b27Akbulut and Tunçay, İstanbul, 120.

105 See Berberian, Roving Revolutionaries.

106 Minassian, Colporteurs du Komintern, 102-16 and 154-62.

107 ASMSAC, Statement of Harutian, 7 April 1922, Busta 388.

108 SHD, Note de Service, 2 May 1922, Renseignements sur Personnes 1922, GR $20 \mathrm{~N} 1104$.

109 SHD, Untitled report, 29 March 1922, Renseignements sur Personnes 1922, GR $20 \mathrm{~N} 1104$.

110 RGASPI, "Zasedaniye Delegatsii Kommunisticheskoy Partii Anatolii i Komorgaizatsii Konstantinopolya," 11 December 1922, 495/154/130/14.

111 SHD, Untitled and undated report about Istanbuli newspapers, Bolchevisme Juin 1921-Juillet 1922, GR 20 N 1106.

112 SHD, Rapport, 14 September 1921, 1919-1920-1921 Renseignements et Compte-Rendus au Sujet des Personnes, GR 20 N 1104.

113 See Allawi, Faisal I of Iraq.

114 Masalha, "Faisal's Pan-Arabism," 679.

115 SHD, "Relations Turco-Communistes de Constantinople avec Angora, 1921, Carton 38/4, GR 20 N 1106.

116 See Yerasimos, Türk-Sovyet Ilişskileri.

117 SHD, "Relations Turco-Communistes de Constantinople avec Angora, 1921, Carton 38/4, GR 20 N 1106.

118 As careful readers might have noticed, this is the third communist sailor named "Mehmet" that we have seen. Although it is intriguing to toy with the idea of them being the same person, given that Mehmet is a highly frequent name in Turkish, it is difficult to substantiate that. 
119 SHD, "Projet d'un Vol de Munitions," 6 March 1921, Renseignements 1921, GR 20 N 1103.

120 Akbulut, Milli Azadlık Savaşı Anıları, 84-7.

121 RGASPI, Untitled letter to Comintern, 2 July 1937, 495/266/12(1)/112.

122 Marie, Histoire de la Guerre Civile Russe, 281-9.

123 SHD, "Zasedaniye Konstantinopolskoy Organizatsii R.K.P,” 6 February 1921,
Bolchevistes et Justice Militaire Folder, GR 20 N 1141.

124 SHD, Procès-Verbal, 13 March 1921, Bolchevistes et Justice Militaire Folder, GR 20 N 1141.

125 SHD, "Liste des Personnes Actuellement Ecrouées," May 1921, Carton 38/4, GR $20 \mathrm{~N} 1106$.

126 SHD, Procès-Verbal-Boris Ivanovitch Onitchenko, 21 March 1921, Bolchevistes et Justice Militaire Folder, GR 20 N 1141. 